\title{
Miranda
}

Revue pluridisciplinaire du monde anglophone /

Multidisciplinary peer-reviewed journal on the English-

speaking world

$21 \mid 2020$

Modernism and the Obscene

\section{John Burnside, The Music of Time: Poetry in the Twentieth Century}

\section{Wayne E. Arnold}

\section{OpenEdition}

\section{Journals}

\section{Electronic version}

URL: http://journals.openedition.org/miranda/30023

DOI: 10.4000/miranda.30023

ISSN: 2108-6559

Publisher

Université Toulouse - Jean Jaurès

\section{Electronic reference}

Wayne E. Arnold, "John Burnside, The Music of Time: Poetry in the Twentieth Century", Miranda [Online],

21 | 2020, Online since 13 October 2020, connection on 16 February 2021. URL: http:// journals.openedition.org/miranda/30023 ; DOI: https://doi.org/10.4000/miranda.30023

This text was automatically generated on 16 February 2021.

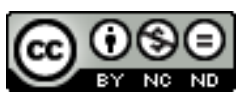

Miranda is licensed under a Creative Commons Attribution-NonCommercial-NoDerivatives 4.0 International License. 


\title{
John Burnside, The Music of Time: Poetry in the Twentieth Century
}

\author{
Wayne E. Arnold
}

\section{REFERENCES}

John Burnside, The Music of Time: Poetry in the Twentieth Century (Princeton University Press, 2020), 510 pp. ISBN 978-0-691-20155-9

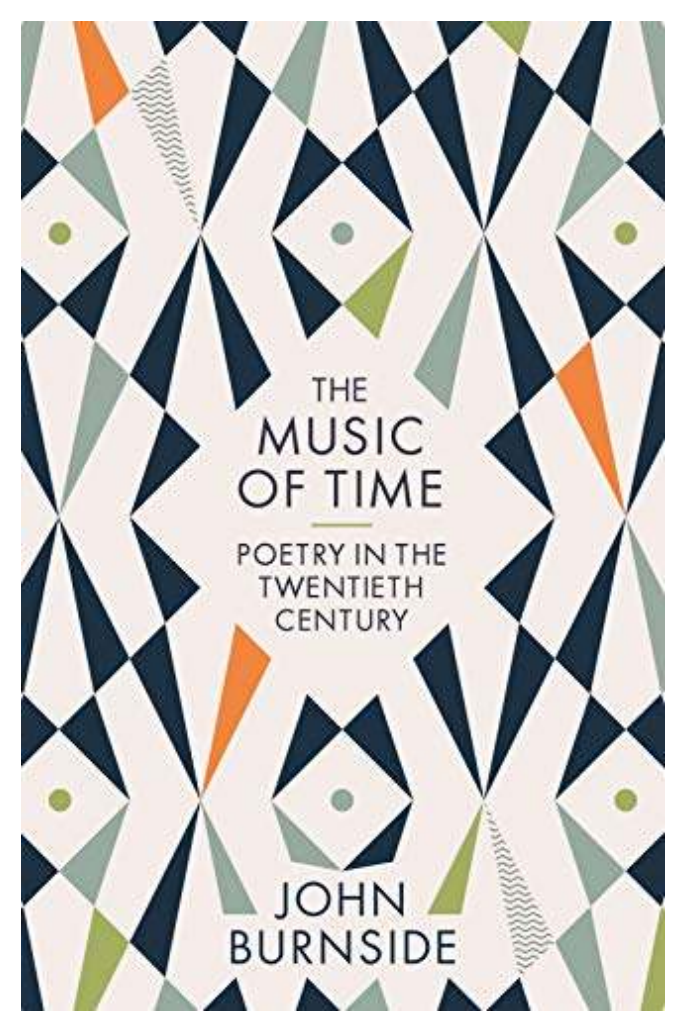


1 Somewhere in Arncroach, Scotland, John Burnside is reading and writing. Perhaps he is perusing Henry Miller (his previous Princeton publication was on Miller), or perchance he is delving into unknown poetry from the Ivory Coast; he may very well be working on his eighteenth volume of poetry. Burnside, if nothing else, is a prolific artist and critic. In his most recent publication, The Music of Time, the poet-cum-novelist delivers an expansive representation of his versatility involving his medium of choice: poetry. Sprawling across twenty-three diverse chapters, Burnside guides us along a meandering path of $20^{\text {th }}$ century verse, endeavoring to connect a variety of themes under the canopy of modernity. The title of his work is intriguing in that we may expect Burnside to show us a beautiful tonality in poetry encircling a variety of poetic genres; instead, he argues that "music-making is a way of making sense of noise," and in turn, "poetry is a way of ordering experience" (12). Experience is gained with time; to grapple with the hardships that life brings our way, Burnside encourages us to learn from the noise-altering music of poetry. The varied cacophonies during the $20^{\text {th }}$ century were, periodically, devastating and catastrophic: the impacts on the individual were no less critical. "The music of what happens" (12), Burnside posits, can guide us in approaching the vastness of the past in relation to where we stand today. The text is intended for our present global situation, and The Music of Time meanders across various topics that remain ever-present in our environment (politically and socially) by studying the songs of the poets who were best positioned to record the significance of events unfolding around them.

2 The Music of Time is a political text. It may seem odd to draw comparisons between a Scottish poet and the United States, but nearly every theme in the 2020 United States presidential election is present in Burnside's writing. For good reason. Early on, Burnside makes clear that "the first strong influences that guided me as a poet were American" (17). The environment, Black Lives Matter, fake news, political leaders, the human condition, and international politics, among others, are present. Surprisingly missing, however, is any gender-focused poetic discussion-a significant oversight in a well-thought-out collection of verse. Nevertheless, Burnside demonstrates his adeptness in melding a variety of political and social topics into an engaging examination, with the overall purpose of trying to make sense of discordances, via poetry. While the overtones may be political, the text does not bombard readers with the current global political climate. Several parts avoid direct reference to politics, focusing instead on nature or human relations. The topics of each section seem specifically chosen to highlight the significance of poetry in terms of political art, and Burnside illustrates how the music generated by poetry helps us understand the varied noises surrounding certain historical and even current events.

3 Poetry is communal, Burnside states (25). From this position, he then engages with his selected poets to muse over numerous events that are often present in daily life (work, travel, marriage, family, the natural world, etc.), and global influences on our societies (wars, racism, class, politics, environmental devastation, loss of culture, etc.). Take for instance the approach to the institution of marriage, and marriage/divorce poems. Legitimate value exists in a poem "that gets out the dissecting kit and digs deep into what makes modern marriage so difficult, on the one hand, and so rewarding when it is sustained, on the other" (328). Looking primarily at the poetry of Robert Graves, Louise Glück, and Alan Shapiro, gives witness to noxious relationships, as in Glück's “Mock Orange" (1968), or the difficulties of indefinitely maintaining a marriage, as shown in 
"Anger," from Shapiro's Tantalus in Love (2005). Increasingly in the $20^{\text {th }}$ century, Burnside states, the "polarity of romantic engagement versus institutional obligation found expression in the works of poet after poet as unrealistic matrimonial expectations were more openly discussed and divorce rates soared" (328).

This marital fallout is part of the noise surrounding our modern lives; but we need not fear, as Burnside explains, while utilizing the poetry of Robert Graves, since Graves finally discovered "that, far from losing themselves in one another, true lovers turn outward to the world and learn how to live there more skillfully than they would otherwise have done" (331). Poetry is not self-help verse waiting to be read, and Burnside is not imploring us to direct our lives through couplets and sonnets, yet there is definite worth to be found in the personal experiences of poets.

5 As noted, The Music of Time has a political lean. Multiple sections deal with the triumvirate of politics, philosophy, and poetics. "A Golden Age of Poetry and Power" conjoins politics and poetry most clearly. It looks at the relationships between President John F. Kennedy, Robert Frost, and Frost's diplomatic trip to Russia in August 1962. The chapter, which briefly touches on the American Dream, refugees (in relation to Emma Lazarus's sonnet), and Geraldo Rivera, primarily focusses on the bond between president and poet. It is obvious from the chapter's title that Burnside considers this period the apex of $20^{\text {th }}$ century American poetry when the country's greatest living poet read at an inauguration and then would travel as a representative to Russia shortly before the Cuban Missile Crisis. Frost and Kennedy's relationship aside, Burnside highlights the link between politics and culture (250); this connection, as intimated elsewhere in the book, has been continually weakened before and after this particular golden age, as poetry is avoided by the greater populace and the media deteriorates its image. While Frost's relationship with Kennedy ultimately came to a dramatic ending, the significance of Frost's presence on inauguration day 1961 is meaningful. Burnside laments that American presidents have drifted away from a willing association with poets (18); it may have been to his gratification then that Democratic party nominee Joe Biden quoted Seamus Heaney in his acceptance speech on August 21, 2020. Heaney is featured in The Music of Time and Burnside concludes his thoughts on the poet with the following summation: "To anyone reading Heaney the risible contention that poetry is politically ineffective is like saying that raising a child or planting a tree is a waste of time" (438). Frost's association with Kennedy is obvious, and with Biden Burnside has been buffered concerning his evaluation of Heaney's poetry.

6 Hope is a bit of an overplayed political word these days (see Biden's selection of the Heaney poem); nevertheless, throughout the previous century of verse, Burnside believes that hope and poetry have been intrinsically entwined: "Hope is the essence, then, for all poets. We might even say that to make a poem at all is an act of hope" (11). Poetry helps us deal with the noise arising from the daily, social, and global events that occur over time, and interpretation of poetic words enables us to reimagine the noise into a type of music (11). This transformation is built on the embodiment of hope. Burnside's text is fairly consistent in this overarching theme of noise, poetry, music, hope-although he notes that most of the poets with which he engages are rather depressing and depressed individuals.

7 Several parts hinge around the theme of nature and animals, both of which are connected with the environment. In "Why Look at Animals," Burnside provides one of 
the more engaging discussions concerning how modern humans have lost touch with nature-specifically, the presence of wild animals in our lives. Echoing Henry David Thoreau's endorsement for the West and wildness in his essay "Walking" (1862), or perhaps mindful of the feckless Christopher McCandless as portrayed in John Krakauer's Into the Wild (1996), Burnside stresses that a possible "sense of being bereft comes from living day to day with the near-absence of wild things." Corresponding to the increasing decrease in our chances to experience natural wild animals, "the obliteration of vast numbers of species during the last hundred years or so has been paralleled by the steady growth in animal encounter poetry" (208). Included are poems that deal with deer, snakes, bees, the animal Other, and even a poem about suicide in the jaws of lions. The chapter is an absorbing gambol through nature, with Burnside arguing that humans are hungry for something lost, "an almost unbearable homesickness for our own wild selves and for the other animals" (233). Nature, animals, and the environment are easy elements to find in poetry, but Burnside's selections are particularly acute in that the verses do not need manipulation to help elucidate his themes.

This newest Burnside publication is an enjoyable read; the chapters are short, and the content and poetry keep the reader's interest. The Music of Time does have its political undercurrents, but these do not detract from the major argument that poetry can help us transform the noise of our lives into music that, if anything else, might help us whistle while we struggle. Part of Burnside's literary prowess appears in his nearseamless incorporation of a wide spectrum of philosophers. From the Greeks to the modern theorists, Burnside can illustrate how certain thought patterns have echoed across the centuries. There is, however, a sense of clandestineness on Burnside's part concerning the content, even the title could be considered misleading. This concealment comes about in a couple of subtle ways. First, the section titles are obscure -what is involved with a chapter entitled "Where Turtles Win"? (think Lawrence Ferlinghetti). What will be discussed in this place filled with winning turtles? (methinks non-academic poetry). The second manner by which the themes seem hidden is with the index. While a 23-page index is lengthy and well appreciated-recording every artist, poem, and book mentioned-there are very few terms listed concerning the themes. In this sense, with both the titles and the index, every chapter remains a relative mystery until read. The text also feels like it lingers in the first half of the $20^{\text {th }}$ century, or at least Burnside seems to draw on additional poets from that era. Most importantly, Burnside deftly keeps his argument on track, only occasionally becoming ambiguous, and he emboldens us to "stay attuned to the music we have been given, rather than trying to create a perfect harmony that can never exist" (461). Here is a worthwhile endeavor by Burnside, one that demonstrates his knowledge of language and its importance in the shape of poetry. 
INDEX

Mots-clés: poésie, $\mathrm{XX}^{\circ}$ siècle, environnement, politique américaine, rêve américain, espoir, animaux

Keywords: poetry, 20th century, environment, American politics, American dream, hope, animals

\section{AUTHORS}

\section{WAYNE E. ARNOLD}

Associate professor of American studies

The University of Kitakyushu, Fukuoka, Japan

waynearnold55@gmail.com 